\title{
A Case of Laryngeal Closure for Dysphagia Following Percutaneous Dilatational Tracheostomy
}

\author{
Takayuki Ota ${ }^{1)}$, Koichiro Nishiyama ${ }^{2)}$, Kazuo Matsui $^{1)}$, Kouichi Kure ${ }^{1)}$, \\ Yoshihiko Esu ${ }^{1)}$, Yutaka Miyoshi ${ }^{3)}$ and Kana Kinoshita ${ }^{4)}$
}

In recent years, there are many reports about percutaneous dilatational tracheostomy (PDT). This procedure has been reported as being simple to perform and has less complications. However, we experienced a case in which a tracheostoma stenosis and granulation hyperplasia occurred due to PDT, and dysphagia occurred because of the defective laryngeal elevation.

A 79 years old woman presented with disturbance of consciousness due to a subarachnoid hemorrhage and PDT was performed at an intensive care unit. Following the procedure she was quadriplegic with dysphagia and had to continue rehabilitation. Because of the dysphagia and difficulty in the management of the tracheotomy tube, she was referred to us.

We selected laryngeal closure as preventive surgery against aspiration, and obtained a good result.

PDT complications have also been reported in several studies.

As the procedure is performed blindly, the tube may not be placed medially in the trachea or it may happen to break tracheal cartilages. When particularly long-term breathing management is necessary, we think that surgical tracheotomy associated with very few occurrences of tracheostoma stenosis and granulation hyperplasia is desirable.

In addition, the operation that we performed was useful because it was hard to make a diastasis and it was easy to make a permanent tracheal stoma. In those patients with a tracheostoma and dysphagia, we would like to recommend a laryngeal closure operation.

Keywords : percutaneous dilatational tracheostomy (PDT), tracheostoma stenosis, dysphagia, preventive surgery against aspiration, laryngeal closure

\section{References}

1) Silverster W, Goldsmith D, Uchino S, et al. : Percutaneous versus surgical tracheostomy: A randomized controlled study with long-term follow-up. Crit Care Med 34: 2145-2152, 2006.

2) Gravvanis AI, Tsoutsos DA, Iconomou TG, et al. : Percutaneous versus Conventional Tracheostomy in Burned Patients with Inhalation Injury. World J Surg 29: 1571-1575, 2005.

3）上原彰史, 竹久保賢, 中山健司, 他 : 経皮的気管切開術の 経験. 新潟医会誌 120: 513-517, 2006 .

4）鹿野真人, 桑畑直史, 高取 隆, 他：長期臥床症例に対す る輪状軟骨鉗除を併用する声門閉鎖術．喉頭 20：5-12, 2008.

5) Toy FJ and Weinstein JD : A percutaneous tracheostomy device. Surgery 65: 384-389, 1969.

6) Ciaglia P, Firsching R and Syniec $C$ : Elective percutaneous dilatational tracheostomy. A new simple bedside procedure; preliminary report. Chest 87: 715-719, 1985.

7）筒井理仁，小泉有美馨，松田憲昌，他：経皮的気管切開術
後に気管切開孔上部の狭窄をきたした 2 例. 蘇生 27：55$59,2008$.

8) Antonelli M, Michetti V, Di Palma A, et al. : Percutaneous translaryngeal versus surgical tracheostomy: A randomized trail with 1-yr double-blind follow-up. Crit Care Med 33: 1015-1020, 2005.

9) Koitschev A, Simon C, Blumenstock G, et al. : Suprastomal tracheal stenosis after dilational and surgical tracheostomy in critically ill patients. Anaesthesia 61: 832-837, 2006.

10) Raghuraman G, Rajan S, Marzouk JK, et al. : Is tracheal stenosis caused by percutaneous tracheostomy different from that by surgical tracheostomy? Chest 127: 879-885, 2005.

11）平野 隆, 上村尚樹, 渡辺哲生, 他: 気道確保における経 皮的気管切開術と外科的気管切開術の比較検討 耳鼻咽喉 科医の観点から〜．日気管食道会報 58：472-477, 2007.

12）湯本英二：誤嚥性肺炎一最近の考方方一 耳鼻咽喉科医の 立場から一鱟下の仕組みとその障害, とくに誤嚥性肺炎一 の対処一. 日胸臨 68: 829-839, 2009.

13) Lindeman RC : Diverting the paralyzed larynx: a reversible procedure for intractable aspiration. Laryngoscope 85: 157-
1) Department of Otolaryngology, Seirei Yokohama Hospital

2) Nishiyama ENT Clinic

3) Nagamachi-Miyoshi ENT Clinic

4) Department of Otorhinolaryngology, Seirei Hamamatsu General Hospital
Corresponding Author Address : Takayuki Ota

t-ota@sis.seirei.or.jp 
180, 1975.

14) Yarington $C T$ and Sutton D : Clinical experience with tracheoesophageal anastomosis for intractable aspiration. Ann Otol Rhinol Laryngol 85: 609-612, 1976.

15) Biller HF, Lawson $\mathrm{W}$ and Baek SM : Total glossectomy: a technique of reconstruction eliminating laryngectomy. Arch Otolaryngol 109: 69-73, 1983.
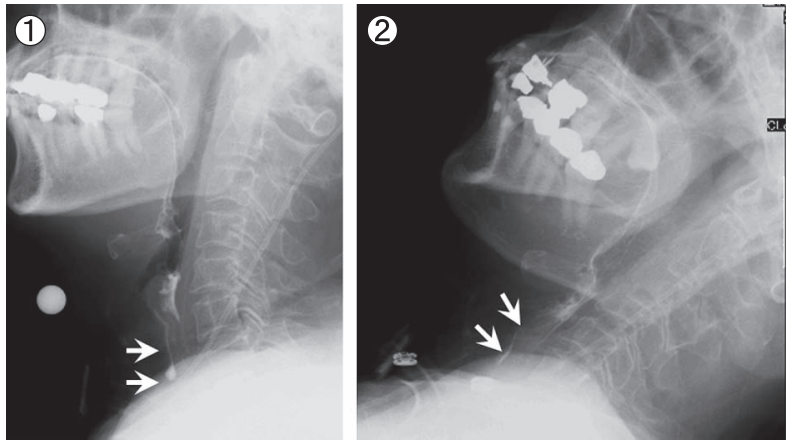

VF findings

(1) sitting position, (2) $30^{\circ}$ reclining position.

Both (1) and (2) had aspiration.
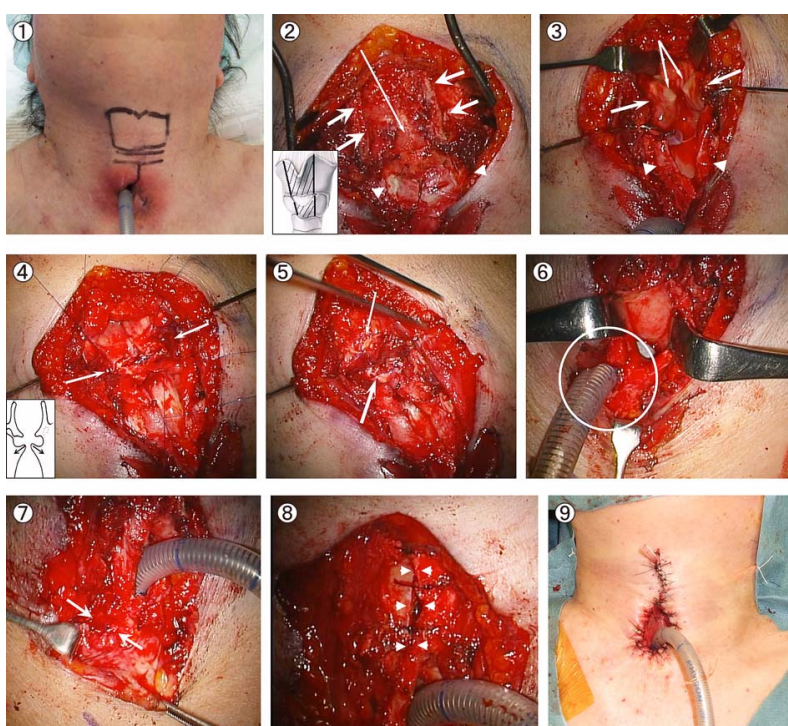

Operation findings

(1) The trachea stoma was displaced.

(2) The median of the thyroid cartilage and the cricoid cartilage were removed.

Thin arrow: cricothyroid membrane, Big arrow: resection stump of thyroid cartilage

Arrowhead: resection stump of cricoid cartilage

(3) Median of the cricothyroid membrane was cut and the arytenoid cartilage (thin arrow) and vocal cord (big arrow) are now in the field of view.

Arrowhead: trachea

(4) The vocal cord (arrow) and the arytenoid cartilage were divided into the upper parts and lower parts.

(5) Each tissue was sutured closed.

Thin arrow: upper part of vocal cord, Big arrow: lower part of vocal cord,

(6) The trachea stoma is out of position to the right.

(7) The trachea was sutured (arrow).

8 The thyroid cartilage was sutured together.

Arrowhead: resection stump of thyroid cartilage.

(9) The trachea stoma is big enough.
16) Habal MB and Murray JE : Surgical treatment of life-endangering chronic aspiration pneumonia. Use of an epiglottic flap to the arytenoids. Plast Reconstr Surg 49: 305-311, 1972.

17) Montgomery WW : Surgery to prevent aspiration. Arch Otolaryngol 101: 679-682, 1975.

18）北原 哲，田部哲也，中之坊学，他：璜下障害に対する気 管食道分離手術。日気管食道会報 50：603-608, 1999.
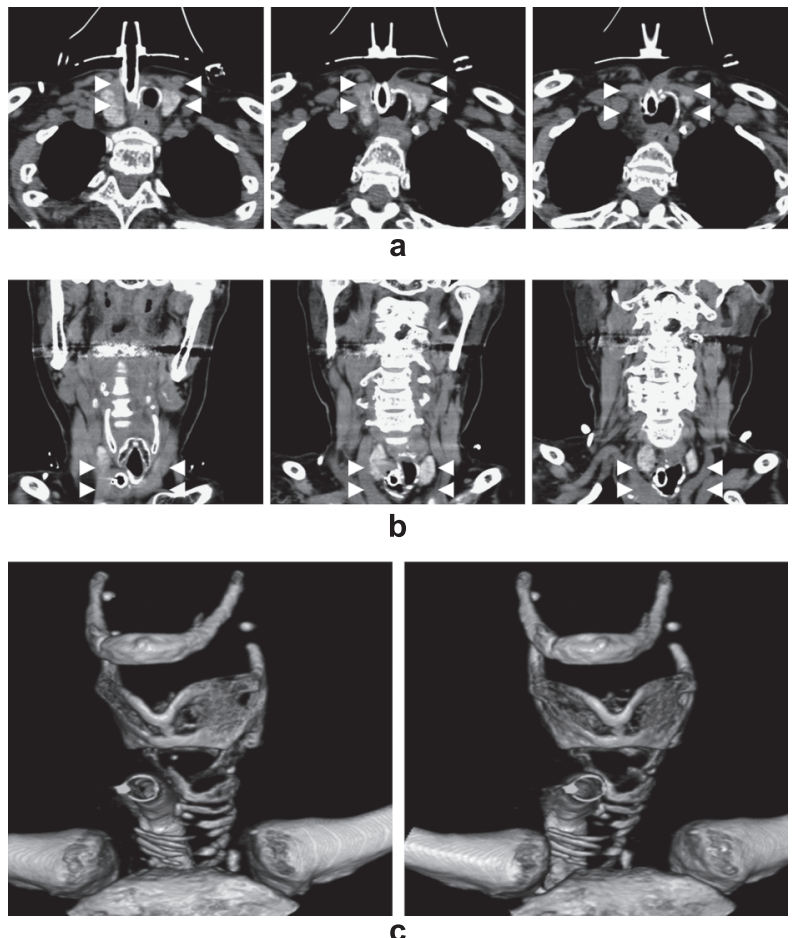

Preoperative CT findings

a: horizontal section, b: coronal section, c: 3D Volume Rendering. The CT shows that a trachea cannula is inserted by the right flank of the trachea. It also shows that tracheal cartilages are crushed.

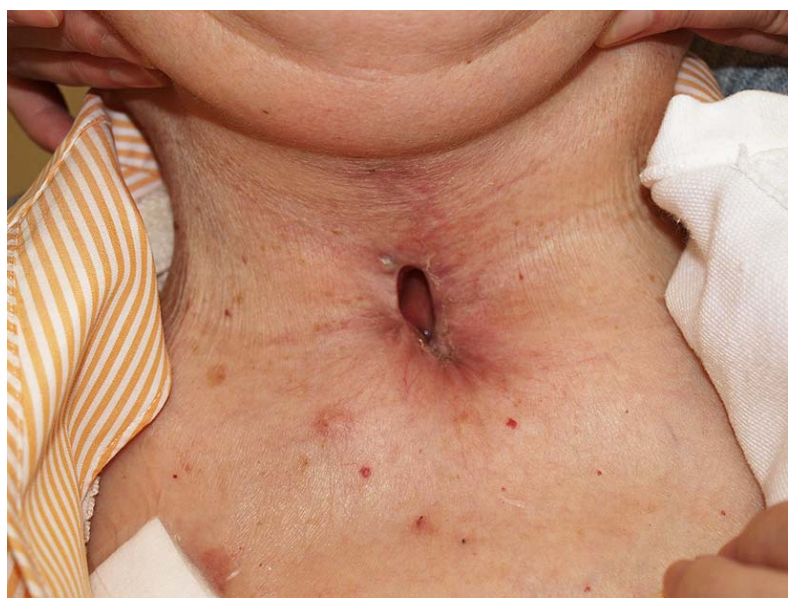

Permanent tracheal stoma (Postoperation) 